Fedirko Anna, Postgraduate Student, Department of Management, National Technical University of Ukraine «Igor Sikorsky Kyiv Polytechnic Institute», Kyiv, Ukraine

ORCID ID: 0000-0002-3691-7748

e-mail: nafAnjka19@gmail.com

\title{
Formation of Competition Policy of the Enterprise in the System of Corporate Governance
}

Introduction. Competition as the basis of the entire market system is an incentive to ensure the smooth functioning of the market. Implementation of effective competition policy implies ensuring equal opportunities for economic entities in the creation and further activity of any organizational structure, access to resources, establishment of reasonable prices and other conditions for the sale of goods, protection against anti-competitive practices, corrupt actions of the authorities, etc. The article defines the peculiarities of the formation of the enterprise competitive policy in the system of corporate management tools and investigates the theoretical and methodological aspects of corporate management tools as a basis for improving the competitiveness of enterprises. The author describes the system of corporate culture as a social and discursive phenomenon, an integral part of enterprise management aimed at the internal environment.

Purpose. Based on the urgency of the problem of research, the purpose of the article is to determine the peculiarity of the formation of competitive enterprise policy in the system of corporate management tools.

Results. The tendencies of the development of modern enterprises are analyzed and the necessity of enterprise management is provided, which will ensure the competitiveness of enterprises on the basis of the model of corporate governance strategy and the influence of corporations on the formation of their competitiveness. The author notes that the effective functioning of the enterprise in current economic conditions is possible with constant analysis of external and internal environments and timely implementation of adequate measures for adaptation to changing conditions. In such circumstances, the concept of "competition advocacy" is introduced. The content of which is understood as being conducted by a competitive agency in the field of stimulating economic activity in a competitive environment through non-enforcement mechanisms, but mainly through interconnection with other state structures and through raising public awareness of the benefits of competition and incorporating all actions of the antitrust authorities, which are not related to enforcement of the rules in the field of antitrust law, but are aimed at forming a competitive culture in society.

Conclusions. It is concluded that a high level of corporate culture is an important strategic factor that mobilizes all structural units of the corporation and its individual employees to achieve the stated goals within the stated mission. It is possible to achieve this level through the corporate governance system which means a set of behaviors, basic ideas and values that are proclaimed and formed by the group in the course of joint activity, and are passed on to new members of the group as effective ways of internal integration and adaptation to change the external environment.

Keywords: competition policy; competition advocacy; corporate culture; levels of corporate culture, corporate governance; corporate governance.

удк 334.722

Федірко Г. А., аспірант кафедри менеджменту, Національний технічний університет України «Київський політехнічний інститут імені Ігоря Сікорського», м. Київ, Україна

\section{Формування конкурентної політики підприємства у системі корпоративних засобів управління}

Конкуренція як основа всієї ринкової системи є стимулом забезпечення нормального функціонування ринку. Реалізація ефективної конкурентної політики передбачає забезпечення рівних можливостей суб'єктів господарювання у питаннях створення та подальшої діяльності будь-якої організаційної структури, доступу до ресурсів, встановлення обгрунтованих цін та інших умов реалізації товарів, захисту від антиконкурентних, корупційних дій органів влади, тощо. у статті визначаються особливість формування конкурентної політики підприємства в системі корпоративних засобів управління, досліджуються теоретико-методичні аспекти корпоративного управління як основи підвищення конкурентоспроможності підприємств. Автор окреслює систему корпоративної культури як соціального та дискурсивного феномену, складової управління підприємством, що спрямована на внутрішнє середовище.

Метою статті є визначення особливостей формування конкурентної політики підприємства в системі корпоративних засобів управління.

Проаналізовано тенденції розвитку сучасних підприємств і обгрунтовано необхідність управління підприємством, що забезпечить конкурентоспроможність підприємств на основі моделі стратегії корпоративного управління та впливу корпорацій на формування їх конкурентоспроможності. Зазначено, що ефективне функціонування підприємства в сучасних економічних умовах можливо при постійному аналізі зовнішнього та внутрішнього середовищ і своєчасному вживанню адекватних заходів щодо адаптації до умов, що змінюються. $3 а$ таких обставин введено поняття «адвокатування конкуренції», зміст якого розуміється як таке, що проводяться 
конкурентним відомством у сфері стимулювання економічної активності в конкурентному середовищі шляхом не правозастосовних механізмів, а головним чином за рахунок взаємозв'язку з іншими державними структурами та за допомогою підвищення обізнаності суспільства щодо переваг конкуренції та включає всі дії антимонопольних органів, не пов'язані з примусом до виконання правил у сфері антимонопольного законодавства, а спрямовані на формування у суспільстві конкурентної культури.

Зроблено висновок про те, що високий рівень корпоративної культури є важливим стратегічним фактором, що мобілізує всі структурні ланки корпорації та ї̈ окремих працівників на досягнення поставлених цілей у межах задекларованої місії. Досягти такого рівня можливо за допомогою системи корпоративних засобів управління до яких відноситься: сукупність моделей поведінки, базових уявлень та цінностей, що проголошуються і формуються групою в ході здійснення спільної діяльності, а також передаються новим членам групи як ефективні способи внутрішньої інтеграції й адаптації до змін зовнішнього середовища.

Ключові слова: конкурентна політика; адвокатування конкуренції; корпоративна культура; рівні корпоративної культури; корпоративне управління; корпоративні засоби управлінняю.

Problem Statement. In the country, where virtuous prevails competition for consumers to choose the goods, which is the cheapest and the best quality, and the entrepreneurs are forced to produce, namely the products, which is chosen by the consumer and sell her at the acceptable price. That is why, from managers at individual enterprises to the leaders highest-ranking should be should be specialists who really understand meaning of competition policy and recognize its need for entrepreneurial activity.

In other words, can speak not only of competition policy, but of a culture of competition at all levels of management, that, unfortunately, in Ukraine for years of formation of market economy, has not search its formation and development. Therefore, corporate governance becomes an integral part of the development ensuring sustainable economic growth of domestic enterprises.

Corporate culture as one of the highly specialized domains of social culture has row own characteristics. Therefore, today's considerable accumulation of experience in the field of competition policy and corporate governance, there is a multifaceted set of various approaches, but science and practice have not yet developed a single clearly delineated system of concepts, which often leads to ambiguous interpretation and uncertainty. Without diminishing the significance of numerous scientific developments, to the question of forming a competitive policy of the enterprise in the system of corporate means management did not find its full coverage, and therefore, it is an important problem that requiring detailed research at this time.

2Analysis of recent research and publications. Theoretical and applied aspects of competition policy have been considered in the works of such foreign scientists as J. Keynes, J. Kirzner, A. Marshall, V. Pareto, M. Porter, J. Robinson, A. Smith, J. Stiglitz, F. Hayek, E. Chamberlain, J. Schumpeter, and others. Among the foreign scientists that involved in the study of the selected problem should also be noted G. Azoev, S. Bru, J. Wilson, J. Gelbreit, E. Gelhorn, Charles V. Gila, V. Eremenko, O. Zhidkova, Y. Ivanov, V. Cairns, N. Klein, M. Knysh, V. Kovachich, A. Kozirin, Y. Korobov, K. McConnell, D. Mial, F. Knight, V. Oiken, S. Parashchuk, L. Ramensky, D. Ricardo, D. Ross, Y. Tinbergen, K. Totyev, R. Fatkhut- dinov, N. Fonarev, P. Heine, V. Tzapelik, F. Scherer, A. Yu. Yudanov, N. Yacheistova, etc.

Significant contribution to the development of different aspects of corporate governance and competitiveness have done by domestic researchers: O. Amosha, S. Bogachev, I. Bueyev, O. Vakulchyk, A. Voronkova, E. Grigorenko, G. Kozachenko, A. Melnyk, G. Nazarov, V. Pavlov, E. Palig, O. Povazhny, M. Sirosh, O. Sokhatska, B. Stetsenko, M. Chumachenko. Separate aspects of the implementation of the national competition policy are reflected in the scientific works of such domestic authors as: G. Androschuk, V. Bazilevich, O. Bakalinskaya, S. Bila, I. Dakhno, O. Doroshenko, B. Kvasnyuk, O. Kilievich, D. King, N. Korchak, L. Kuzmenko, V. Mamutov, S. Mochernyi, V. Nevmerzhitsky, G. Pasternak-Taranushchenko, O. Paskhaver, N. Saniakhmetova, L. Semenova, V. Tiravsky, V. Chagarovsky, O. Shnyrkov, etc.

Corporate culture research and its components are dedicated to the work of representatives of different fields of scientific knowledge: economics and management (T. Peters, R. Waterman), the theory of personnel management (A. Asaul, P. Erofeev, C. Fombrun), linguistic (R. Breeze, O. Kolobov, T. Annanko, J. Garzone, M. Ozerov), cultural studies (T. Persikova, P. Tikhomirov, V. Spivak), psychologies (E. Shane), etc. In their work of the scientists corporate culture is presented one form of social culture that emerges and exists in accordance with the laws, are identical to any other type of culture.

The methodological framework of the research is concluded in totality of special and general scientific methods and present scientific knowledge. Of course,to achieve a specific goal and decision set given out tasks are applied the following methods: dialectical, logical, methodological analysis, generalization, scientific abstraction, large analysis.

Formulation of research objectives. In accordance with the goals of research article is implemented the following tasks: research theoretical and methodological aspects of corporate governance as a basis for increasing the competitiveness of enterprises; determine corporate culture system as a social and discursive phenomenon, constituting management of the enterprise that is directed to the internal environment; to analysis of the development trends of modern enterprises and to justify 
need for the management of the enterprise that ensure competitiveness of enterprises based on the model of corporate governance strategy and the influence of corporations on formation of their competitiveness.

The presentation of the basic material research. A characteristic feature of the modern economy is the process of continuous change. The condition of survival of social and economic systems, concluded in their continuous change, in the diversity of economic setups and the freedom to convert to any one of them, in the radical change in the value of market feedback.

Traditional Ukrainian management with its orientation to high profit; the univariant strategies that are being developede as a rule exclusively by top managers; bureaucratic multilevel organizational management structures; formulating plans from the top down and hard vertical control system - are no longer able to effectively use the opportunity and to confront threats and challenges of the external environment. Therefore, to ensure successful activity, it is necessary to transition to more progressive management. After all, the business becomes international. Today, the most characteristic of modern managerial thought is considered to be four new trends (Table 1) [4, p. 12].

Table 1 New trends of modern managerial thought

\begin{tabular}{|l|l|}
\hline \multicolumn{1}{|c|}{ Tendency } & \multicolumn{1}{c|}{ Characteristics } \\
\hline the internationalization of management & $\begin{array}{l}\text { Apprehension of new realities are begeted by deepening of the international } \\
\text { division of labor, increasing interdependence in the world economy, the } \\
\text { development of transnational corporations and the international information } \\
\text { systems }\end{array}$ \\
\hline Growth of the international competition & The survival of the most corporations effective \\
\hline Orientation to values & $\begin{array}{l}\text { Social and economic efficiency, realization of the potential workers and the system, } \\
\text { growing preparedness to innovations }\end{array}$ \\
\hline $\begin{array}{l}\text { Combination of different types of } \\
\text { management systems }\end{array}$ & $\begin{array}{l}\text { Both stiffly regulated and based on inner freedom dependent upon accepted } \\
\text { organizational culture and human relations }\end{array}$ \\
\hline
\end{tabular}

Source: [4, p. 12]

For enterproses which structure is centralized, it becomes clear that decentralized management technologies (for example, delegation of powers, selfmanagement) are unsuitable. Often, the need to improve the management of individual objects or increased effectiveness of their functioning arises immediately for several areas of enterprise activities. In this case there arises the problem of choosing highpriority directions of technology introduction or formation of a chain of priority of such directions [3].

For decision of this problem it is proposed to use principle of liquidation of bottlenecks in management, first of all liquidation bottleneck in the management system. At that, it is necessary to take into account the socalled "the pyramid strategies" of a certain enterprise. Where to level of senior management develops a general (corporate) strategy that taking into account opportunity to take a certain position in the market in the near future.

An effective implementation of this level strategies are ensured by a corporate culture that based on basic ethical norms and principles of activities. In various corporations, such values may be different, including depending on whose interests are at the heart of the company's activities - the company itself or its individual members [6].

For the rest another level of the hierarchy of strategies (Figure 1), one of the effective ways of decision of the problem of competitiveness of the enterprise is business process management, an effective tool, of which is a longterm competitive strategy of activities of the organization.
Under competitive strategy implies long-term complex interconnected activities are directed to ensuring sustainable competitive advantage, content profitable durability of competitive position and ensuring the desired level of competitiveness.

Despite this, such a generalization does not reflect all the important aspects that can make the chosen strategy effective. It is about enterprise opportunity and dynamic (flexibility, adaptability), market situation or else external influence factors [7].

Therefore, competition policy is contained not only a strategy, but also a tactics that specifies strategic goals and focuses on decision of high-priority tasks. At that it is important to understand its functional appointment. Preliminary analysis allows form system goals of competition policy that provides for strategic and tactical and intermediate.

In our opinion, under such circumstances, should be introduced such concept as of "competition advocacy". The content of which is understood as that conducted by a competitive agency in the sphere of stimulation of economic activity in a competitive environment way of non-law enforcement mechanisms, and mainly through relationship with other state structures and by means of raising awareness of the society on benefits of competition and include all actions of antimonopoly authorities, not related to compulsion to fulfillment rules in the sphere of antimonopoly legislation, but but are directed to forming in competitive culture society. 


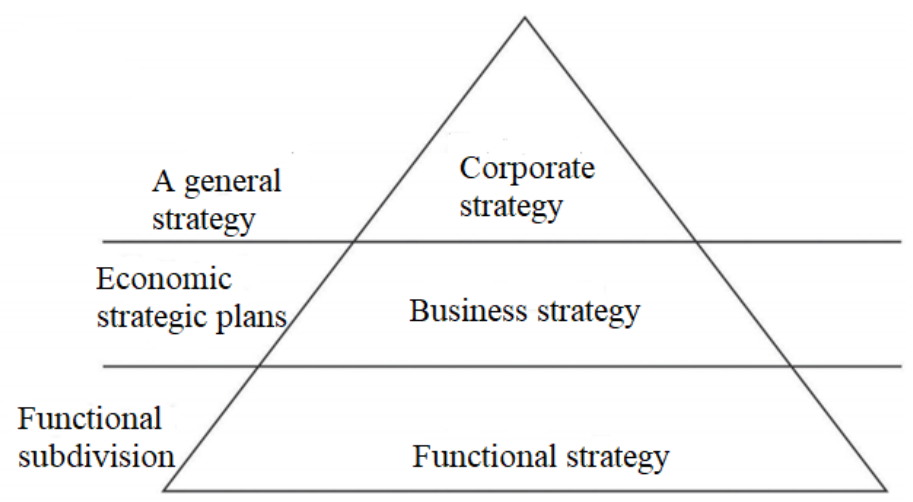

Figgure 1 - The pyramid strategies

Source: [2]

Such an approach gives the opportunity to identify tactics for achieving the competitive goals of the enterprise to form of a sustainable competitive advantage at the intersection of external opportunities and internal unique properties enterprise. In other words, the effective functioning of the enterprise in the modern economic conditions, possibly with constant analysis of external and internal environments and timely adoption of adequate measures to adapt to changing conditions.

Foreign experience shows that one of the effective means increase productivity without changes in the material and production base, a means of strengthening the loyalty of employees and preservation personnel potential of the company, the company image, which plays an important role in its success in the market, there's the corporate culture that consists not only of "public" elements of a company's activity, such as advertising activity, participation in various events, promotion of products, branding and rebranding processes and so on. It also applies to daily work of the company's offices, documents that it's constituent of " life activity ", corporate code of ethics, prescribed development strategies and promotion of products, reports, project documents, etc. [10, p. 74].

One of the founders of corporate culture theory is American psychologist E. Shane. Under corporate culture, he understands "what the organization has learned from its experience as a social unit" and includes here philosophy and ideology of governance, values and beliefs, installation and norms. Corporate culture, according to E. Shane, is the model of norms of behavior that members of the organization have already used in the past and recognized as true, and, consequently, it's need to give for the assimilation of all new members of the organization as the only true way of perception, submissions and relationships within the organization [9, p. 54-55].

According to E. Shane's model, within organizations exist to direct and indirect mechanisms of functioning and interaction. The corporate culture model of an organization depends directly on direct mechanisms. They include exemplary behavior, thoughts, statuses and appointment of workers. Indirect mechanisms do not the influence of the corporate culture directly however they are a decisive factor. They include mission of the company, official guidance principles, corporate style, identity, design and rituals.

E. Shane defines three levels of corporate culture[9, $p$. 89]:

1. level artifacts - the most of the surface is visible from the outside level of corporate culture that includes all external manifestations of culture, which is able to apprehend a person (technology, architecture, logos, organizational folklore, uniforms, etc.). Artifacts require further concretize, since can be interpreted differently;

2. the level of meaning and values - a deeper level of corporate culture, which manifests implicitly and is expressed either by interaction with the physical environment or through social consensus. Value orientations are determined by the direction of the organization development, is asked by the trajectory of its development and promote improved business effictiveness;

3. the level of basic glances, in which stand out from the existing worker glances, which is impossible to change or to evaluate, however, they influence of the life activity and the culture of the organization. This could be certain personal beliefs which remain hidden, but can influence on corporate culture, and also the internal aspects of human nature. To thank such aspects are formed intuitive rules and practices of corporate culture inside a certain organization - they are not discussed, but arise education on method of "social agreement". Such rules make up the third level of corporate culture.

Similar to the three-level model of corporate culture is also called "the Iceberg model" since they are based on different layers. The external layer is easily enough to adapt and easily change. Than deep layer, the harder it is to change becomes. Deep glances are rooted in this model, they reflect basic concepts of all people which belong to organization, flowing out of their experience and perception. Around the nucleus with glances are located values. 
Enterprises reflect the values and ideology of the society, to whom they belong. Therefore, they can be considered as subcultures with own corporate identity, they are institutions task which is strengthening the ideological distortion of society, and also to support the legality beliefs and values of that society and its members. In such perspective of different corporate cultures are organizational manifestations, which reflect the broad institutional mechanism of interaction between business, workers, and control systems directed to support concrete social ideology [8, p. 118-126].

In T. Persikova research of phenomenon of corporate culture comes to the conclusion that large companies have a more developed corporate culture compared to medium and small businesses. This is explained in greater orientation on satisfaction of the needs collective, in order not to lose "components" of the well-functioning mechanism of successful work of the company. Exactly therefore, large corporations can allow yourself to invest money in the process of team building, development artifacts of corporate identity, inculcating in the workers respect and pride in the company in which they work [5, p. 18].

As part of research, and taking into account nearness our glances to the definition given by T. Ananko, it is better to hold to the definition of corporate governance proposed by the researcher that, acting as component of the company's activity, corporate governance corresponds to the basic provisions of corporate culture and is "composite of the corporate culture of the company; factors that determine the character and organization of corporate governance, related to the directions of activity of the company, rules and norms of corporate behavior, and also corporate culture values»[1, p. 5].

Conclusions. Upon the results of research was identified that a high level of corporate culture is an important strategic factor that is mobilizing all structural links corporation and her separate workers to achieve set goals in the limits declared the mission. At that, in general understanding corporate culture is presents yourself to certain system of material and spiritual values, norms of behaviour and interaction, inherent in certain organization that reflecting her individuality.

In other words, to the corporate governance means of system includes: totality model of behaviors, basic presentation and values that are proclaimed and formed by the group in the course of implementing joint activities, and also hand over new group members as effective ways of internal integration and adaptation to changes in the external environment. After all, if you do not take into account the implementation of "ideas of the collective reason" based on the values of the enterprise, that contains yourself of the ideology of socio-economic development activities of the enterprise, will not be achieved the main goal of strategic management of business processes of the enterprise, that is change "bifurcation points" to provide business processes of the enterprise condition management differentiated. That is, must be developed the program development corporate governance of specific enterprise system to avoid uncertainty and unorganized business processes, and also turn into their purposeful planned model the consequence of which is increased by goods turnover development of consumer loyalty program, industry leadership, increasing the number of goods in one receipt, stabilization activities, etc.

Thus, the analysis of the development of tendency of modern enterprises in the conditions of globalization of the economy, it is necessary to implement to the substantiation of the enterprise management strategies that will ensure the competitiveness of enterprises based on the model of corporate governance strategy and the influence of corporations on the formation of their competitiveness.

\section{References:}

1. Ananko, T. R. (2007). Anglophone corporate discourse: Abstract. diss. Cand. philol. Sciences: 10.02.04. Kharkiv, p. 22 [in Ukrainian].

2. Eremenko, A. O. (2018). Corporate governance strategy as a basise for increasimg enterprise competitiveness publishing and printing activities. Scientific notes. Ukrainian academy of book-printing, 1, 208-216 [in Ukrainian].

3. Swan, O. V. (2012). The justification for selection direction of inculcationнологі of management technologies. Economic strategy and development perspective in the sphere of trade and services, 2, 302-308 [in Ukrainian].

4. Patlis, A. G. (2008). Management strategy for unbalanced production system in the unstable external environment: abstract. diss. Cand. econom. of sciences. Saint-Petersburg, 23 [in Russ].

5. Persikova, T. N. (2007). The phenomenon of corporate culture in modern Russia: a comparative analysis of corporate cultures in Russian and foreign organizations: abstract. diss. Cand. econom. of sciences: 24.00 .01 . Russia, 25 [in Russ].

6. Polyanskaya, A. S. \& Duke, A. N. (2018). Formation model of corporate culture in activity of domestic enterprises. The black sea economic studio, 27(2), 9-16 [in Ukrainian].

7. Shvets, Yu. O. (2016). The influence of the external and internal environments factors on the efficiency of strategic management reverse means of mechanical engineering enterprises. Herald of Zaporizhzhia National University. Economic sciences, 1, 26-36 [in Ukrainian].

8. Peters, T. \& Waterman, R. (2004). In Searchof Excellence: Lessonsfrom America's Best-Run Companies. Harper Collins. 367 p.

9. Schein, E. (2009). The Corporate CultureSurvivalGuide. Sloan Management Review, p. 53-127

10. Stanford, N. (2015). The Economist Guideto Organisation Design. 2nd ed. Profile Books, 533 p. 